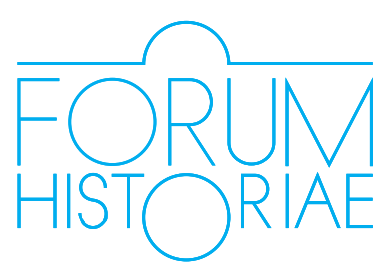

\title{
Autonómia Slovenska 1938 - 1939: Počiatočná fáza holokaustu a perzekúcií (Úvod)
}

\author{
Martina Fiamová - Michala Lônčíková
}

\begin{abstract}
:
FIAMOVÁ, Martina - LÔNČÍKOVÁ, Michala: Slovak Autonomy 1938 - 1939: The Initial Phase of the Holocaust and Persecution (Introduction).

The end of the 1930s was critical for the democratic regime of the Czechoslovak Republic and the international situation after the signature of the Munich agreement on $29^{\text {th }}$ September 1938. The movement for autonomy for Slovakia resulted in the declaration of Slovak autonomy on $6^{\text {th }}$ October 1938. The Hlinka's Slovak People's Party (HSL'S) immediately started to establish a single ruling party system. During this relatively short 6-month period, until the declaration of the Slovak State in March 1939, significant political changes were dramatically implemented. The conservative, nationalist, and Christian regime of the HSLS initiated the process of forming a "new" Slovakia under the protective umbrella of Nazi Germany, including the struggle against its enemies - real and also fictitious. The move to Slovak Autonomy represented a significant transition period when the planning and organisation of the initial phase of the Holocaust and the persecution of other potential opponents was begun by political representatives.
\end{abstract}

Keywords: Slovak Autonomy 1938 - 1939, Jews, Political Persecution

DOI: https://doi.org/10.31577/forhist.2019.13.1.1

$\mathrm{T}$ akmer dve desat'ročia vývoja prvej Československej republiky (ČSR) spečatila koncom septembra 1938 Mníchovská dohoda, ktorou Nemecko, Taliansko, Francúzsko a Vel'ká Británia donútili Československo ustúpit' nacistickým územným požiadavkám. Dohoda však v konečnom dôsledku vyústila do zmien spoločných hraníc nielen s Nemeckom, ale aj s Pol'skom a Mad’arskom a otvorila slovenskej politickej reprezentácii možnost' doriešit' dlhoročný problém štátoprávneho postavenia Slovenska a Slovákov. Vzhladom na to sa pražská vláda rozhodla pristúpit' na autonomistické požiadavky Hlinkovej slovenskej l'udovej strany (HSL'S) až v októbri 1938. HSL’S bola najsilnejšou stranou na Slovensku, podliehala ale predstave, že jedine ona má právo zastupovat' záujmy slovenskej spoločnosti. ${ }^{1}$ Z tohto hladiska sa stalo klúčovým zasadnutie klubu poslancov a senátorov HSL'S zvolané na 5. októbra 1938 do Žiliny. Napriek tomu, že tu zazneli aj návrhy na utvorenie samostatného štátu, presadila sa predstava budovania slovenskej štátnosti v rámci spoločného štátu. $\mathrm{V}$ dňoch 5. a 6. októbra $1938 \mathrm{v}$ Žiline nakoniec vznikli tri zásadné dokumenty, ktoré sa súhrnne označujú ako Žilinská dohoda slovenských politických strán. Išlo o Vyhlásenie, ktoré podpísali zástupcovia prítomných strán - HSL'S, Slovenskej národnej strany (SNS), agrárnej a fašistickej

1 BYSTRICKÝ, Valerián. Vznik Slovenského štátu. In HRADSKÁ, Katarína - KAMENEC, Ivan a kol. Slovensko v 20. storočí. Zv. 4. Slovenská republika 1939 - 1945. Bratislava : Veda, 2015, s. 17-34. 
strany. Politické strany sa tak prihlásili k návrhu ústavného zákona o autonómii, ktorý v lete podala HSL'S, pričom deklarovali, že „ústavným prijatím tohto návrhu bude štátoprávne postavenie Slovenska definitívne vyriešené“. Druhým dokumentom bol návrh zákona o decentralizácii vládnej moci vypracovaný a podpísaný zástupcami agrárnej strany, SNS, fašistickej strany, národnými socialistami a živnostenskou stranou. Podla neho vládnu a výkonnú moc na území Slovenskej krajiny vykonávala slovenská vláda zložená z piatich ministrov. Zákon mal platit' do ustanovenia autonómnej vlády ústavným zákonom. HSL'S súčasne v Žiline prijala Manifest slovenského národa, ktorý schválilo užšie predsedníctvo strany 6. októbra 1938 a Jozef Tiso ho predniesol na zasadnutí výkonného výboru strany. V Manifeste HSL'S vyzdvihla prirodzené právo národa na sebaurčenie a postavila sa za "mierové vyriešenie sporných problémov v duchu mníchovskej dohody", pričom zdôraznila, že „vytrváme po boku národov bojujúcich proti marxisticko-židovskej ideológii rozvratu a násilia “2 . Členovia vlády Jana Syrového v Prahe prijali zásady Žilinskej dohody a ešte 6. októbra 1938 v zastúpení prezidenta republiky bol J. Tiso vymenovaný za ministra pre správu Slovenska. Na druhý deň sa slovenskými ministrami stali aj Matúš Černák, Ján Lichner (agrárnik), Pavel Teplanský (agrárnik) a Ferdinand Ďurčanský. Na základe dohody slovenských ministrov s ústrednou vládou prešli na nich kompetencie v slovenských záležitostiach dovtedy, kým nebudú definitívne usporiadané podla ústavného zákona, ktorý bol nakoniec prijatý 22. novembra 1938. Podla tohto zákona vládnu a výkonnú moc na území Slovenskej krajiny vykonávala krajinská vláda, zodpovedná Snemu Slovenskej krajiny, a to spätne od 7. októbra 1938. Túto moc mala vykonávat' vo veciach patriacich do jej právomoci dovtedy, kým nebude utvorená Slovenská krajinská vláda menovaná prezidentom na návrh predsedníctva slovenského snemu. Ústavný zákon tiež podrobne vymedzil právomoci Národného zhromaždenia, ktorými disponovalo pre územie celej republiky, od čoho sa následne odvíjal aj rozsah vládnej a výkonnej moci česko-slovenských orgánov na území Slovenska. ${ }^{3}$

Ústavný zákon umožnil vytvorenie Snemu Slovenskej krajiny, ktorý bol zvolený vo vol’bách 18. decembra 1938. Pri ich organizácii sa prejavili nedemokratické

2 LETZ, Róbert. Vyhlásenie autonómie Slovenska. In ROGUL’OVÁ, Jaroslava a kol. Pramene k dejinám Slovenska a Slovákov. Slováci a druhá svetová vojna. XIII a. Bratislava : Literárne informačné centrum, 2015, s. 20-21.

3 „\$ 4. (1) Národné shromaždenie vykonáva zákonodarnú moc pre celé územie Česko-Slovenskej republiky vo veciach: 1. ústavnej listiny, jej čiastok, ako ajv otázkach upravujúcich činnost' spoločných zákonodarných, vládnych a výkonných orgánov; 2. vzt’ahov Česko-Slovenskej republiky $k$ cudzine, vypovedania vojny a uzavretia mieru, obchodnej a tarifnej politiky, vývozu a dovozu; 3. národnej obrany; 4. štátneho občianstva, vyst'ahovalectva, pristahovalectva, cestovných pasov; 5. meny, mier a váh, veci patentov, ochrany vzorkov a ochranných známok, vymerovania a mapovania; 6. colných; 7. dopravy; 8. pošty, telekomunikácií, poštovnej sporitel'nej a šekovej služby; 9. spoločného rozpočtu, spoločnej uzavierky, štátneho dlhu a schval'ovania pôžičiek pre spoločné potreby štátu a ich použitia; 10. daní, dávok a poplatkov, nakol'ko tieto podla $\$ 18$ tohto zákona slúžia na krytie výdavkov spoločných vecí, zásad nepriamych daní vôbec; 11. monopolov, spoločných štátnych podnikov, ústavov a zariadení. Výnimku tvoria štátne lesy a majetky, banské a hutnické podniky, kúpele, ktorých vlastníctvo a správa prechádza na tú krajinu, na území ktorej sa nachádzajú; 12. právnej úpravy otázok hospodárskych a finančných, ktoré sú potrebné k zabezpečeniu rovnakých sút'ažných podmienok podnikania. (2) Na základe súhlasu snemu Slovenskej krajiny Národné shromaždenie môže jednotne riešit' aj iné otázky spoločného záujmu...\$11. (1) Vládnu a výkonnú moc na území Slovenskej krajiny vo veciach uvedených $v$ \& 4 tohto zákona vykonávajú orgány republiky Česko-Slovenskej okrem bodov 4, 6, 7, 8, 10 a 12 \& 4 tohto zákona... § 15 . (1) Vo veciach, pod bodmi 4, 6, 7, 8, 10 a 12 \& 4 ako aj v ostatných v $\& 4$ tohto zákona neuvedených veciach, vládnu a výkonnú moc vykonávajú autonomné orgány Slovenskej krajiny. (2) Vo veciach bodu 6 a 10 \& 4 pokračujú krajinské orgány podla predpisov spoločných ministerstiev." Sbírka zákonů a nařízení státu československého, ústavný zákon č. 299/1938 Sb. z. a n. zo dňa 22. novembra 1938 o autonomii Slovenskej krajiny. 
spôsoby konania vládnucej strany, ktorá si želatel’ný výsledok volieb „poistila“ viacerými opatreniami. Napríklad vyhláška o vol'bách do snemu vyšla v sobotu 26. novembra $1938 \mathrm{~s}$ tým, že kandidátne listiny museli byt' odovzdané do nasledujúceho dňa do 12 hod., čím bolo znemožnené podat' kandidátku inej politickej strany ako HSL'S - Strany slovenskej národnej jednoty. Ďalším z neštandardných krokov bolo rozdelenie volebných miestností podla národnostného princípu, umožňujúce kontrolu hlasovania a lojality občanov. ${ }^{4}$

Po prvom zvolaní snemu a zvolení jeho predsedníctva podala Tisova vláda 19. januára 1939 demisiu, v dôsledku čoho bolo možné vymenovat' vládu Slovenskej krajiny spôsobom, akým to určoval ústavný zákon o autonómii. Prezident republiky Emil Hácha (na návrh predsedníctva snemu) preto následne vymenoval novú slovenskú vládu, ktorej predsedom a ministrom vnútra sa stal opät' Jozef Tiso.

Vládnuca HSL'S od samého začiatku usmerňovala vývoj v krajine s cielom vybudovat' na Slovensku autoritatívny systém, čo sa jej do vel'kej miery darilo. V krátkom čase zlikvidovala politickú pluralitu (v procese núteného zjednotenia strán s HSL'S alebo rozpustením nepohodlných politických subjektov) i opozičnú tlač, začala prenasledovat’ svojich odporcov. V l'udáckej tlači sa objavili články apelujúce na vytvorenie vlastných koncentračných táborov. Už v čase autonómie sa vyskytli prípady mimosúdneho internovania politických oponentov s „nevhodnými“ názormi do tábora v Ilave, hoci jeho štatút bol ustanovený až v marci 1939, teda doslova pár dní po vzniku Slovenského štátu. ${ }^{5}$ Súčasne v spoločnosti rástla úloha polovojenských oddielov strany - Hlinkovej gardy (HG). ${ }^{6}$ Začali sa otvorené útoky na „nepriatelov a škodcov“ národa, najmä Čechov a Židov. Tieto, v interpretácii luudákov neslovenské, resp. protislovenské elementy mali byt' podla HSL'S odstránené zo spoločnosti, čím by zároveň uvol'nili priestor Slovákom. Národný princíp (vyjadrený heslami „Slovensko Slovákom “ či „Na Slovensku po slovensky") vytváral však aj istú brzdu ambicióznych požiadaviek nemeckej národnostnej menšiny, ktorá vzhladom na svoje nadštandardné postavenie vystupovala značne sebavedome. ${ }^{7}$

Voči Čechom sa režim vymedzil hned' v októbri 1938, reprezentovaný hlasmi žiadajúcimi odchod českých zamestnancov, či dokonca všetkých Čechov zo Slovenska. Odsun pritom nebol len programom HSL'S, podporovali ho predstavitelia viacerých strán (SNS, agrárnici). ${ }^{8}$ Podl'a nich sa tak mal vyriešit' problém, ktorý už dlhé roky vnášal napätie a nevraživost' medzi oba národy a súvisel s nedostatkom slovenskej inteligencie po prvej svetovej vojne. Kým pred rokom 1918 žilo na Slovensku 7468 Čechov, koncom roka 1938 ich bolo 93143 (3,4%). . K 1. októbru

4 NIŽŇANSKÝ, Eduard. Vol'by do snemu slovenskej krajiny v roku 1938. In Studia Historica Nitriensia VII, 2003, s. 163-2003.

5 ZAVACKÁ, Marína. L’udácka prevýchova. Mária Janšáková v Ilave roku 1939 a jej Cela číslo 20. Bratislava : Artforum, 2018, 37-38.

6 BYSTRICKÝ 2015, s. 24.

7 KAMENEC, Ivan. Vnútropolitický vývoj Slovenskej republiky v rokoch 1939 - 1945. In HRADSKÁ, Katarína

- KAMENEC, Ivan a kol. Slovensko v 20. storočí. Zv. 4. Slovenská republika 1939 - 1945. Bratislava : Veda, 2015,

s. $153-155$.

8 BYSTRICKÝ, Valerián. Od autonómie k vzniku Slovenského štátu. Bratislava : Prodama s. r. o, 2008, s. 190.

9 Podla krajinského súpisu z konca roka 1938 žilo na Slovensku viac ako 77 tisíc osôb českej národnosti, z ktorých väčšina tu nemala domovské právo. BYSTRICKÝ 2008, s. 184; RYCHLÍK, Jan. K otázke postavenia 
1938 pracovalo na území Slovenska v štátnej správe vrátane podnikov 21541 štátnych zamestnancov českej národnosti (okrem príslušníkov vojenskej správy) a spolu s Čechmi zamestnanými v súkromnom sektore mohlo íst’ asi o 36000 pracovníkov. ${ }^{10}$ Decembrovou dohodou z roku 1938 s českou stranou mala dat' slovenská vláda Prahe k dispozícii 9000 českých štátnych zamestnancov (predovšetkým osôb bez definitívy). ${ }^{11}$ Protičeské nálady v časti slovenskej spoločnosti súčasne vyhrocovala verejná kampaň, ktorá následne vyvolávala negatívnu reakciu v českej časti populácie.

Ku konkrétnym opatreniam slovenskej vlády, ktorými sledovala odstránenie „nevhodných" osôb zo slovenského verejného, hospodárskeho či politického života, patrili zásahy do samosprávnych orgánov, vedenia živnostenských komôr, zastavenie a zakázanie činnosti niektorých politických strán alebo zákaz športových spolkov (k ich rozpusteniu došlo v decembri 1938, pričom majetok prešiel na HG, ktorá sa stala jedinou telovýchovnou organizáciou na Slovensku).

Osobitnú pozornost’ si zaslúžia snahy o elimináciu židovskej komunity vo viacerých oblastiach života na Slovenku. V niektorých smeroch sa jej síce dotkli aj zásahy zamerané vo všeobecnosti proti oponentom režimu, iné však boli orientované vyslovene proti Židom. Z tých hospodárskych spomeňme napr. obmedzenie podnikania hlavne ortodoxných Židov už v októbri 1938 nariadením o nedel'nom odpočinku, či nariadenie o dočasných obmedzeniach v živnostenskom podnikaní - ochrana pred „nekalými živlami“, ktorého ustanovenia sa mali prísne aplikovat’ proti „neprajníkom slovenského národa“, a to zvlášt' židovského vierovyznania a národnosti. Nariadenie vlády Slovenskej krajiny o obmedzení zat’aženia nehnutel'ností malo zase zabránit' prevodu nehnutel'ného majetku do „cudzích rúk“ a urobit' všetko preto, aby sa dostal do rúk krest’anov. Zmenený prístup úradov naznačovalo aj nariadenie o súpise hostinských a výčapníckych živností či kontrola kominárskych koncesií, pri ktorých sa okrem bežných údajov po novom požadovali už aj informácie o národnosti, náboženstve a štátnom občianstve. Proti židovským sudcom bolo namierené nariadenie ministerstva pravosúdia z februára 1939, podla ktorého im nesmela byt' pridel'ovaná súdna agenda v prípade, ak by ju museli vybavovat' ako prejednávajúci sudcovia. Obdobie autonómie bolo navyše vo viacerých slovenských mestách poznačené násilnostami na židovskej komunite (napr. v Trnave, Piešt’anoch a Nitre), ${ }^{12}$ na ktorých sa zúčastňovali členovia HG či propagandou „povzbudená“ verejnost'. Útoky proti Židom sa v tlači vyskytli už po Mníchovskej dohode, no vystupňovali sa v období prípravy prvej Viedenskej arbitráže, na základe ktorej prišlo Slovensko v novembri 1938 o čast' svojho južného územia. ${ }^{13} \mathrm{~V}$ tejto súvislosti je nutné spomenút' najkrutejší zásah

českého obyvatel'stva na Slovensku v rokoch 1938 - 1945. In Historický časopis, 1989, roč. 37, č. 3, s. 403-407. 10 BYSTRICKÝ 2008, s. 184-185.

11 RYCHLÍK 1989, s. 407.

12 NIŽŇANSKÝ, Eduard. Pogrom v Pieštanoch roku 1939. IVANIČKOVÁ, Edita (ed.) Z dejín demokratických a totalitných režimov na Slovensku a v Československu v 20. storočí. Historik Ivan Kamenec 70-ročný. Bratislava : Prodama, 2008, s. 77-97.

13 Pozri MITÁč, Ján (ed.). Juh Slovenska po Viedenskej arbitráži 1938 - 1945. Bratislava : Ústav pamäti národa, 2011. 
proti židovskej komunite na Slovensku v sledovanom období, ked' slovenská politická reprezentácia využila okolnosti k tomu, aby sa zbavila časti „nepohodlných“ obyvatelov.

Vzápätí po prijatí arbitrážneho rozhodnutia 2. novembra 1938 bolo Židom znemožnené odcestovat' či evakuovat' do slovenských oblastí, čím boli donútení ostat' na území odovzdanom Mad'arsku. ${ }^{14} \mathrm{Z}$ rozkazu ministerského predsedu Tisa však 4. novembra došlo k protiprávnemu vyst’ahovaniu časti Židov zo slovenského územia, ked' domáce úrady dostali za úlohu premiestnit' Židov „bez hmotných prostriedkov" hlboko do odstúpených území (nariadenie sa nemalo vztahovat' na Židov cudzej príslušnosti okrem pol'skej, nemeckej, mad'arskej a rumunskej). ${ }^{15}$ $V$ ešte ten istý deň ale dostali okresné úrady nové inštrukcie, podla ktorých mali byt' Židia - pol'skí, nemeckí, mad’arskí, rumunskí cudzinci a bezdomovci okamžite premiestnení na postúpené územie do hĺbky najmenej $20 \mathrm{~km}$. Zároveň Židia bez domovského práva $\mathrm{v}$ obci, v ktorej sa zdržiavali, mali byt' urýchlene vypovedaní do svojich domovských obcí. Akciu, ktorú realizovali četnícke stanice a vedúce jednotky HG a na niektorých miestach i armáda či príslušníci tzv. Légie slobodného Slovenska, sprevádzalo i zaistenie bohatých Židov s majetkom presahujúcim 500000 Kčs s cielom zabránit' im „dajakému odnášaniu majetku“. 0 tom, že slovenská vláda myslela svoj zámer „riešit židovskú otázku“ už v čase autonómie vážne, svedčí aj fakt, že v januári 1939 zriadila na tento účel komisiu, ktorej členmi sa stali Karol Sidor, Pavel Teplanský, Mikuláš Pružinský, Ferdinand Ďurčanský a Július Virsík. ${ }^{16}$

Začiatkom marca 1939 vyhrotili situáciu v krajine mocenské plány Tretej ríše, rastúce odstredivé tendencie $\mathrm{v}$ časti HSL'S a $\mathrm{z}$ toho vyplývajúce stúpajúce napätie medzi pražskou a bratislavskou vládou. ${ }^{17}$ Ústredná vláda sa usilovala zabránit' hroziacej možnosti rozbitia republiky zorganizovaním vojenského zásahu na Slovensku (tzv. Homolov puč z 9. na 10. marca 1939), tento pokus ale skončil neúspešne. Dňa 11. marca 1939 prezident Hácha vymenoval novú vládu Karola Sidora. Nemecké snahy prinútit’ ho k jednostrannému vyhláseniu nezávislosti stroskotali, v Berlíne preto hladali alternatívnu vol'bu. Tou sa nakoniec stal Jozef Tiso, ktorý 13. marca 1939 súhlasil, že odcestuje do Nemecka. Napriek jasnej požiadavke nemeckého kancelára Adolfa Hitlera odmietol Jozef Tiso vyhlásit’ samostatnost' priamo z Berlína. Hitler preto súhlasil so zvolaním slovenského parlamentu na 14. marca 1939. ${ }^{18}$ Snem Slovenskej krajiny v tento deň prijal demisiu vlády Karola Sidora, vypočul si Tisovu správu o výsledku rozhovoru s Adolfom Hitlerom a pod jej vplyvom vyhlásil samostatnost'. Vznik nového štátneho útvaru bol legalizovaný prijatím zákona č. 1/1939 Sl. z., ktorým sa Slovenská krajina vyhlásila za samostatný Slovenský štát. ${ }^{19}$

14 Štátny archív v Nitre, fond (f.) Okresný úrad Zlaté Moravce, kartón (k.) 27, č. j. 1763/38 prez. 15 Štátny archív v Nitre, f. OÚ Zlaté Moravce, k. 28, č. j. 1769/38 prez.

16 Pozri NIŽŇANSKÝ, Eduard - KAMENEC, Ivan (eds.) Holokaust na Slovensku 2. Prezident, vláda, Snem SR a Štátna rada o židovskej otázke (1939 - 1945). Bratislava : NMŠ, ŽNO, 2003, s. 25-26.

17 Pozri BYSTRICKÝ, Valerián - MICHELA, Miroslav - SCHVARC, Michal a kol. Rozbitie alebo rozpad? Historické reflexie Česko-Slovenska. Bratislava : Veda, 2010.

18 BYSTRICKÝ 2015, s. 30-34.

19 Prijatím ústavy 21. júla 1939 bol oficiálny názov krajiny Slovenský štát zmenený na Slovenská republika. Pomenovanie slovenský štát sa vztahuje na celé obdobie jeho existencie od vzniku v marci 1939 do zániku v roku 1945. 
Autonómia Slovenskej krajiny existovala necelých šest’ mesiacov. Hoci išlo z časového hl'adiska o zdanlivo krátke obdobie, na prechod od parlamentnej demokracie sa ukázalo byt’ viac ako dostatočné. Nastolený kurz zmien určovaných HSL'S, ktorej sa promptne podarilo sústredit' do svojich rúk všetku politickú moc v krajine, plynule pokračoval aj po vzniku Slovenského štátu. V období autonómie boli položené základy režimu, ktorý pretrval do roku 1945, ba dokonca mnohé postupy voči oponentom, reálnym i domnelým, mohli byt' inšpiráciou aj pre d’alšiu totalitu, ktorá trvala vyše 40 rokov. Počiatky perzekúcií patria práve do tohto krátkeho „intermezza“, a preto obdobie autonómie považujeme za klúčové pre výskum udalostí z rokov 1939 - 1945. Z tohto dôvodu sme sa rozhodli venovat' toto číslo časopisu Forum Historiae turbulentnému obdobiu rokov 1938 - 1939. Pravdepodobne najviac spracovanou témou v súčasnej slovenskej historiografii sú začiatky holokaustu na Slovensku, avšak jednotlivé štúdie autorov venované osudom židovskej komunity ukazujú, že téma rozhodne nie je vyčerpaná a výskum sa progresívne posúva dopredu. Na druhej strane sme považovali za dôležité poukázat' aj na iné obete perzekúcií a budovania režimu HSL'S komplexnejšie, výsledkom čoho je zaradenie textov zaoberajúcich sa postavením žien, právnym nástrojom novej moci, vplyvu nacistických orgánov na rozbíjaní Československa a budovaní vzájomných kontaktov a spolupráce najmä s radikálnymi predstavitel'mi l'udákov v ned’alekej Viedni.

Toto číslo časopisu Forum Historiae vzniklo v spolupráci s Dokumentačným strediskom holokaustu (DSH) a s podporou projektu European Holocaust Research Infrastructure (EHRI), ktorého slovenským partnerom je DSH.

Cituj:

FIAMOVÁ, Martina - LÔNČíKOVÁ, Michala. Autonómia Slovenska 1938 - 1939: Počiatočná fáza holokaustu a perzekúcií (Úvod). In Forum Historiae, 2019, roč. 13, č. 1, s. 1-6. ISSN 1337-6861. DOI: https://doi.org/10.31577/forhist.2019.13.1.1

$\cdots$

PhDr. Martina Fiamová, PhD. Historický ústav SAV Slovenská akadémia vied P. O. Box 198 Klemensova 19 81499 Bratislava Slovenská republika martina.fiamova@gmail.com
Mgr. Michala Lônčíková

Vienna Wiesenthal Institute for Holocaust Studies

Rabensteig 3,

1010 Vienna

Austria

michala.loncikova@gmail.com 